\title{
Assignment of Vibrio sp. strain ABE-1 to Colwellia maris sp. nov., a new psychrophilic bacterium
}

\author{
Isao Yumoto, ${ }^{1}$ Kosei Kawasaki, ${ }^{1}$ Hideaki Iwata, ${ }^{1,2}$ Hidetoshi Matsuyama ${ }^{2}$ \\ and Hidetoshi Okuyama1,3
}

\author{
Author for correspondence: Isao Yumoto. Tel: +81118578925 . Fax: +81118578900 \\ e-mail: yumoto $\alpha$ hniri.go.jp
}

\footnotetext{
1 Bioscience and Chemistry Division, Hokkaido National Industrial Research Institute, Tsukisamu-Higashi, Toyohira-ku, Sapporo 062-8517, Japan

2 Department of Bioscience and Technology, School of Engineering, Hokkaido Tokai University Minaminosawa, Minami-ku, Sapporo 005-8601, Japan

3 Laboratory of Environmental Molecular Biology, Graduate School of Environmental Earth Science, Hokkaido University, Sapporo 060-0810, Japan
}

\begin{abstract}
A psychrophilic bacterium, previously described as Vibrio sp. strain ABE-1 ${ }^{\top}$, has been reassigned by phenotypic characterization, chemotaxonomic analysis and 165 rRNA phylogenetic analysis. The organism was curved rods and it could reduce nitrate to nitrite and hydrolyse gelatin and DNA, but not chitin. $\mathrm{NaCl}$ was required for growth. This strain was susceptible to the vibriostatic compound 0/129. The major isoprenoid quinone was ubiquinone-8 and the DNA $G+C$ content was $39 \cdot 4 \mathrm{~mol} \%$. The whole-cell fatty acids comprised saturated and monounsaturated fatty acids with 10-18 C atoms; saturated and monounsaturated $C_{16}$ fatty acids were predominant. Strain $A B E-1^{\top}$ contained the unique trans-unsaturated fatty acid, 9-trans-hexadecenoic acid. Although strain ABE-1' has been identified as a Vibrio species, the strain did not ferment glucose. Phylogenetic analysis based on 165 rRNA sequencing indicated that strain ABE-1' was more closely related to Colwellia species than to Vibrio species. However, strain ABE-1T differed from other reported Co/wellia species in terms of phylogenetic position, some phenotypic characteristics, chemotaxonomic analysis and relatedness by DNA-DNA hybridization. Accordingly, the name Colwellia maris is proposed. The type strain is ABE-1' ( = JCM 10085').
\end{abstract}

Keywords: Colwellia maris sp. nov., psychrophilic bacterium, Vibrio

\section{INTRODUCTION}

There have been many reports about micro-organisms that can grow in extreme environments such as low and high temperatures, high pressure, alkaline and acidic conditions, and high chemical concentrations (Horikoshi \& Grant, 1991). Even though the temperature is below $10^{\circ} \mathrm{C}$ in almost $80 \%$ of the Earth, little is known about the taxonomic diversity and physiology of micro-organisms which have adapted to the cold. Morita (1975) defined the psychrophile as having an optimum temperature for growth of about $\leqslant 15^{\circ} \mathrm{C}$ and a maximum temperature for growth of $\leqslant 20^{\circ} \mathrm{C}$, and the psychrotroph as a cold-tolerant organism, with a maximum growth temperature above $20^{\circ} \mathrm{C}$. Compared with mesophiles, there are not many examples of isolation of psychrophiles. However,

The GenBank/EMBLDDBJ accession number for the 16S rRNA sequence reported in this paper is $A B 002630$. several strains have been identified at the species level (Bowman et al., 1997a, b; D'aoust \& Kunshner, 1972; Deming et al., 1988; Gounot, 1976; Irgens et al., 1996; Morita \& Haight, 1964; Pacha, 1968).

A psychrophilic bacterium, Vibrio sp. ABE-1 ${ }^{\mathrm{T}}$, has been isolated previously (Takada et al., 1979). The micro-organism exhibited optimum and maximum temperatures for growth of $15^{\circ} \mathrm{C}$ and below $24^{\circ} \mathrm{C}$, respectively. The cellular fatty acids concerned with cold adaptation (Okuyama et al., 1990, 1991), bioenergetic properties as a marine bacterium (Takada et al., 1981, 1989a, 1991), and enzymology as a psychrophile (Ishii et al., 1987, 1993) of the strain have been studied extensively. However, its taxonomic position at the species level remains to be determined.

In this study, phenotypic and chemotaxonomic characteristics and the phylogenetic position of strain ABE$1^{\mathrm{T}}$ have been examined; results showed that the strain should be classified as a new species. 


\section{METHODS}

Bacterial strains and cultivation. The strain examined was Vibrio sp. ABE- $1^{\mathrm{T}}$ (Takada et al., 1979). It was isolated from seawater which was obtained from the Abashiri coast $\left(44^{\circ} 3^{\prime} \mathrm{N}, 144^{\circ} 16^{\prime} \mathrm{E}\right)$, off the Okhotsuku Sea, in Hokkaido, Japan, in the season when drifting ice from Siberia flowed into the region. The organism was cultivated aerobically until the late exponential phase of growth at $15^{\circ} \mathrm{C}$ in PYSE medium ( $\mathrm{pH} 7 \cdot 5)$, unless otherwise stated. The PYSE medium ( $\mathrm{pH} 7.5)$ contained (per litre $50 \%$ Herbst's artificial seawater) $8.0 \mathrm{~g}$ peptone (Kyokuto), $3.0 \mathrm{~g}$ yeast extract (Merck), and $15 \mathrm{~g}$ agar (if needed). Herbst's artificial seawater contained the following (per litre distilled water): $30 \mathrm{~g}$ $\mathrm{NaCl} ; 0.7 \mathrm{~g} \mathrm{KCl} ; 5.3 \mathrm{~g} \mathrm{MgSO}_{4} .7 \mathrm{H}_{2} \mathrm{O} ; 1.3 \mathrm{~g} \mathrm{CaSO}_{4} .2 \mathrm{H}_{2} \mathrm{O}$; and $10.8 \mathrm{~g} \mathrm{MgCl}_{2} \cdot 6 \mathrm{H}_{2} \mathrm{O}$. Colwellia psychrerythraea ATCC $27364^{\mathrm{T}}$ (type strain) was used as a comparison for the test of metabolism of D-glucose and DNA-DNA hybridization. The strain was grown at $15^{\circ} \mathrm{C}$ on marine agar or broth 2216 (Difco).

Phenotypic characterization. For phenotypic characterization, PYSE medium was used as the basal medium, the culture was incubated at $15^{\circ} \mathrm{C}$ for 2 weeks, and the experiment was performed more than twice unless otherwise stated. Morphological, physiological and biochemical tests were performed as described in Cowan \& Steel's manual (Barrow \& Feltham, 1993). The metabolism of carbohydrates was tested by the method of Leifson (1963). The experiment was repeated five times. The result was checked daily for 1 month after inoculation. Alginase activity was determined after a preparation was overlaid with ethanol following $10 \mathrm{~d}$ incubation. Sensitivity to the vibriostatic agent O/129 (2,4-diamino-6,7-diisopropylpteridine) was determined after 1 week cultivation on PYSE agar plates using diagnostic disks (10 and $150 \mu \mathrm{g}$; Oxoid). The utilization of the substrate as the sole carbon and energy source was performed with USTM medium ( $\mathrm{pH} 7 \cdot 5)$ containing $0.2 \%$ substrate, $50 \mathrm{mM}$ Tris, $190 \mathrm{mM} \mathrm{NH} \mathrm{Cl}_{4}, 0.33 \mathrm{mM} \mathrm{K}_{2} \mathrm{HPO}_{4}$, $0 \cdot 1 \mathrm{mM} \mathrm{FeSO}{ }_{4} \cdot 7 \mathrm{H}_{2} \mathrm{O}$ in $1150 \%$ Herbst's artificial seawater (described above).

Electron microscopy. Cells which were grown on PYSE agar medium were suspended in physiological saline. A small drop of the suspension was placed on a carbon-coated copper grid and negatively stained with $1 \%$ phosphotungstic acid for observation with a transmission electron microscope (Hitachi H-800).

Analysis of isoprenoid quinones. Isoprenoid quinones were extracted by treating $500 \mathrm{mg}$ freeze-dried cells with $150 \mathrm{ml}$ chloroform/methanol $(2: 1, \mathrm{v} / \mathrm{v})$ for $2 \mathrm{~h}$ in a reciprocal shaker (120 strokes per min) at room temperature. The extracted solution was concentrated and transferred by acetone. The resulting solution was concentrated, separated by TLC using $n$-hexane/dimethyl ether $(85: 15, \mathrm{v} / \mathrm{v})$ as the solvent, and recovered from the TLC plate using acetone. The obtained isoprenoid quinones were analysed by HPLC equipped with a Novapak C18 column (Waters) at room temperature. The HPLC system consisted of a solvent delivery pump (model CCPM-II; Tosoh) and a spectrophotometer detector (model UV-8020; Tosoh) set at $275 \mathrm{~nm}$.

Analysis of cellular fatty acids. Whole cell fatty acids were extracted from $100 \mathrm{mg}$ freeze-dried cells, which were cultivated on PYSE medium, esterified by acid methanolysis and analysed by GLC equipped with a flame-ionization detector (model GC-7A; Shimadzu) and a $25 \mathrm{~m}$ BPX70 column (SGE) with an oven temperature of $170^{\circ} \mathrm{C}$. Fatty acids were identified by comparing them with fatty acid methyl ester standards (Supelco) and by GC/MS (model INCOS 50; Finnigan mat) connected to GLC (model 3400; Varian).

DNA base composition and DNA-DNA hybridization. DNA was prepared from bacterial cells by the method of Marmur (1961). The DNA G $+C$ content was determined by the method of Tamaoka \& Komagata (1984). The obtained DNA was digested with nuclease P1 (Yamasa Shoyu). The resulting nucleotides were separated by HPLC. The HPLC system was as described above. An equimolar mixture of four deoxyribonucleotides (Yamasa Shoyu) was used as the standard.

Levels of DNA relatedness were determined fluorometrically by the method of Ezaki et al. (1989) using photobiotinlabelled DNA probes and microplates.

Amplification of 16S rRNA gene and sequencing. The $16 \mathrm{~S}$ rRNA gene was amplified by PCR. The sequences of the primers used for amplification were $5^{\prime}$ AGAGTTTGATCCTGGCT 3 ' and 5' AAGGAGGTGATCCAGCCGCA $3^{\prime}$, corresponding to positions 8-24 and 1528-1544, respectively, in the 16S rRNA sequence of Escherichia coli (Brosius et al., 1978). The $1.5 \mathrm{~kb}$ PCR product was directly sequenced by the dideoxynucleotide chain-termination method with a DNA sequencer (model 377; Applied Biosystems). Multiple alignments of the sequence were performed, nucleotide substitution rates $\left(K_{\text {nuc }}\right.$ value) were calculated, and a neighbour-joining phylogenetic tree (Kimura, 1980; Saitou \& Nei, 1987) was constructed using the Clustal w program (Thompson et al., 1994). The similarity values of the sequences were calculated using the GENETYX computer program (Software Development).

Nucleotide sequence accession numbers. The DDBJ/ EMBL/GenBank accession numbers for the sequences used as reference sequences are as follows: Colwellia-like bacterium S51-W(gv)1 (Gosink \& Staley, 1995), U14581; C. psychrerythraea (DeLong et al., 1993), L10939; small subunit rRNA gene cloned from macroaggregate of the sea (AGG53) (DeLong et al., 1993), L10950; Pseudoalteromonas haloplanktis subsp. haloplanktis ATCC 14393' ${ }^{\mathrm{T}}$ X67024; Shewanella hanedai CIP 1032077\%, X82132; Photobacterium angustum ATCC 25915 ${ }^{\mathrm{T}}$, X74685; Vibrio cholerae ATCC $14035^{\mathrm{T}}$, X74695; Alteromonas macleodii IAM $12920^{\mathrm{T}}$, X82145; Aeromonas hydrophila ATCC 35654, X74676; Escherichia coli (Carbon et al., 1979), J01859; Moritella marinus NCIMB $1144^{\mathrm{T}}$, X82142; Marinomonas vaga ATCC 27119, X67025.

\section{RESULTS}

\section{Morphology}

When the bacterium was grown at $15^{\circ} \mathrm{C}$ in PYSE medium, the cells appeared as single motile curved rods of $0 \cdot 6-0 \cdot 8$ by $2 \cdot 0-4.0 \mu \mathrm{m}$ in size. Flagella-staining light microscopic observation and transmission electron micrograph (Fig. 1) revealed a single polar flagellum. Spore formation was absent and Gramstaining was negative.

\section{Phenotypic characteristics}

Strain $\mathrm{ABE}-\mathrm{1}^{\mathrm{T}}$ exhibited the following physiological and biochemical characteristics. Oxidase and catalase activities were positive. Acids were produced from Dglucose under aerobic conditions; no acids, however, 


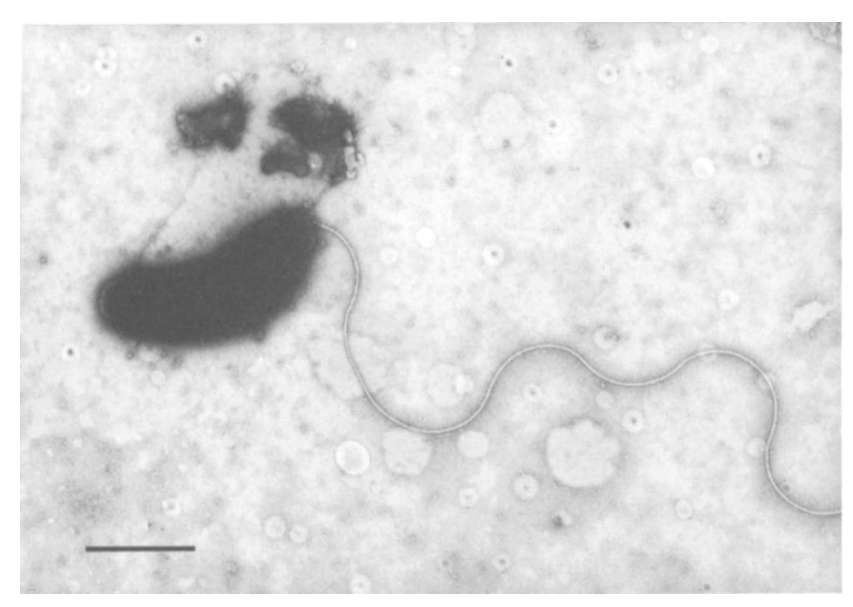

Fig. 1. Electron micrograph of negatively stained cells of strain $\mathrm{ABE}-1^{\top}$ showing curved rod and polar flagellum. Bar, $1 \mu \mathrm{m}$.

were produced under anaerobic conditions. No acids were produced from L-arabinose, D-fructose, maltose, D-mannose, melibiose and sucrose under either aerobic or anaerobic conditions. The strain did not grow in the absence of $\mathrm{NaCl}$ in the culture medium. It grew in media supplemented with 3 and $4 \% \mathrm{NaCl}$, but not in media with salinity higher than $6.5 \% \mathrm{NaCl}$. Susceptibility to the vibriostatic compound O/129 (10 and $150 \mu \mathrm{g})$ was also detected. Growth occurred at $0-22^{\circ} \mathrm{C}$, but not at temperatures higher than $25^{\circ} \mathrm{C}$. The strain was negative for methyl red, VogesProskauer and indole production, but did reduce nitrate to nitrite. It hydrolysed gelatin, DNA and Tweens 20.40,60 and 80, but not casein, chitin, starch or alginic acid. The strain utilized D-glucose as a sole carbon and energy source for growth, but not Dmannose, raffinose, D-xylose, L-arabinose, D-fructose, glycerol, lactose, maltose, melibiose or sucrose.

\section{Chemotaxonomic characteristics}

The isoprenoid quinones isolated from strain $\mathrm{ABE}-1^{\mathrm{T}}$ using TLC were analysed by HPLC. Analysis revealed that ubiquinone-8 (Q-8) was the predominant isoprenoid quinone in the strain.

$\mathrm{GC}$ analysis of the methyl ester derivatives of the fatty acids of the strain revealed that the major components were $\mathrm{C}_{16: 0}(18 \%), \mathrm{C}_{16: 1} 9 t(20 \%)$ and $\mathrm{C}_{16: 1} 9 c(20 \%)$. Smaller, but substantial amounts of $\mathrm{C}_{16: 1} 7 \mathrm{c}(6 \%)$, $\mathrm{C}_{17: 0}(5 \%)$ and $\mathrm{C}_{18: 1} 11 c(6 \%)$ were also detected.

\section{$16 \mathrm{~S}$ rRNA sequence analysis}

The almost complete 16S rRNA sequence of strain ABE- $1^{\mathrm{T}}$. consisting of 1514 nucleotides, showed $92.9 \%$ similarity to the 16S rRNA sequence of $C$. psychrerythraca, whereas its similarity to the sequences of Pseudoalteromonas, Shewanella, Photobacterium, Vibrio, Moritella, Alteromonas, Escherichia, Pasteurella and Aeromonas species was less than $90 \%$. The strain showed high similarity $(97 \cdot 8 \%)$ with a gas vacuolate bacterium, strain S51-W(gv)1 (Gosink \& Staley, 1995), isolated from Antarctica. However, this strain has not yet been identified at the species level. Strain ABE-1 ${ }^{\mathrm{T}}$ also clustered with amplified 16S rRNAs of AGG53 (DeLong et al., 1993) and PVB OTU12 (Moyer et al., 1995) (data not shown) which were isolated from sea macroaggregate and a hydrothermal vent system, respectively. The $16 \mathrm{~S}$ rRNA sequence of strain ABE$1^{\mathrm{T}}$ exhibited high similarity to that of AGG53 $(95 \cdot 3 \%)$ and PVB OTU12 (92.9\%).

\section{DNA base composition and DNA-DNA hybridization}

The DNA $\mathrm{G}+\mathrm{C}$ content of strain $\mathrm{ABE}-\mathrm{l}^{\mathrm{T}}$ was $39.4 \mathrm{~mol} \%$, a value that falls within the definition range of the genera Colwellia and Vibrio.

According to $16 \mathrm{~S}$ rRNA sequence analysis, strain ABE- $1^{\mathrm{T}}$ was closely related to the genus Colwellia. Only two species belonging to genus Colwellia, $C$. psychrerythraea and Colwellia hadaliensis, have previously been recognized. However, the type strain of C. hadaliensis is difficult to obtain. Therefore, the level of DNA relatedness between strain ABE- $1^{\mathrm{T}}$ and only obtainable species, C. psychrerythraea ATCC $27364^{\mathrm{T}}$, was determined; this value was $22 \%$.

\section{DISCUSSION}

Phenotypic characterization and chemotaxonomic analysis of strain ABE- $1^{\mathrm{T}}$ in this study were comparable to previous results (Okuyama et al., 1990; Takada et al., 1979, 1989b), except for the casein hydrolysis and DNA $G+C$ content results. Strain $\mathrm{ABE}-1^{\mathrm{T}}$ was tentatively identified as belonging to the genus Vibrio, due to the characteristic phenotypic similarities to Vibrio marinus, although it has been reported as being negative for fermentation of $D$ glucose (Takada et al., 1979). In the present study, in addition to the phenotypic characteristics, the almost complete sequence of the 16S rRNA was determined. Phylogenetic analysis based on the 16S rRNA sequence revealed that strain $\mathrm{ABE}-1^{\mathrm{T}}$ was more closely related to Colwellia species than to Vibrio species (Fig. 2 ). These results suggest that strain ABE- $1^{T}$ should be classified as Colwellia rather than Vibrio.

Although phylogenetic analysis has revealed that the genera Colwellia and Vibrio are very different (Fig. 2) and strain $\mathrm{ABE}-1^{\mathrm{T}}$ and $C$. psychrerythrae do not ferment D-glucose, Colwellia species have been described in the genus Vibrio in terms of phenotypic characterization (Holt et al., 1994). Actually, the Colvellia strains, C. psychrerythraea and C. hadaliensis, have been reported as facultatively anaerobic bacteria (D'aoust \& Kunshner, 1972; Deming et al., 1988), but in this study, generally (four-fifths of trial), C. psychrerythraea did not produce acids from D-glucose under either aerobic or anaerobic conditions during 1 month. However, acids were occasionally produced under aerobic conditions (one-fifth of trial). These results suggested that phenotypic characteristics of the genus Colwellia may also be totally different from 




0.01

Fig. 2. Phylogenetic tree derived from 165 rRNA sequence data of strain ABE-1 ${ }^{\top}$ and other species within the gamma 3 subclass of the class Proteobacteria. Marinomonas vaga was used as outgroup for the gamma 3 subclass of Proteobacteria. Bar, 0.01 $K_{\text {nuc }}$.

those of the genus Vibrio. It is considered that there are several difficulties in judging Leifson's modified oxidation/fermentation test (Leifson, 1963) due to the long period of incubation at low temperature when studying psychrophiles. Interestingly, the Colwellia species are more closely related to Alteromonas macleodii (Fig. 2), a strictly aerobic marine bacterium, than to facultative anaerobes, such as the genera Vibrio, Photobacterium and Aeromonas, on the basis of phylogenetic analysis. From the results described above, it is concluded that strain ABE- $1^{\mathrm{T}}$ belongs to the genus Colwellia, and that the definition of Colwellia should be amended in terms of D-glucose metabolism.

The phenotypic characterization of halophilic genera that commonly occur in marine habitats is shown in Table 1. The genus Colwellia can be differentiated from four other genera of halophilic marine microorganisms on the basis of phenotypic and chemotaxonomic characteristics as follows: genera Vibrio, Photobacterium and Moritella are facultatively anaerobic; and the genus Halomonas exhibits a $\mathrm{G}+\mathrm{C}$ content of DNA of $52-68 \mathrm{~mol} \%$ and the major isoprenoid quinone detected is Q-9. However, it is very difficult to differentiate between the genus Colwellia and the genera Alteromonas, Pseudoalteromonas, Shewanella and Marinomonas using these characteristics. In some cases, it is possible to differentiate between strain $\mathrm{ABE}-1^{\mathrm{T}}$, which belongs to the genus Colwellia, and the cold-adapted strains that belong to these other genera on the basis of phenotypic and chemotaxonomic characteristics. For example, recently, Pseudoalteromonas antarctica was isolated from an Antarctic coastal environment (Bozal et al., 1997). Strain ABE- $1^{\mathrm{T}}$ was differentiated from $P$. antarctica in terms of cell shape, growth temperature range $\left(4-30{ }^{\circ} \mathrm{C}\right)$, utilization and metabolism of substrates, nitrate reduction and starch hydrolysis.

The available data of phenotypic characteristics of the already known Colwellia species, $C$. psychrerythraea and C. hadaliensis, are limited (D'aoust et al., 1972; Deming et al., 1988). Strain ABE-1 $1^{\mathrm{T}}$ can be differentiated from the other two reported Colwellia species on the basis of phenotypic characteristics and DNA $\mathrm{G}+\mathrm{C}$ content as follows: $C$. psychrerythraea produces red pigment, hydrolyses starch and has a growth temperature range of $0-19^{\circ} \mathrm{C} ; C$. hadaliensis hydrolyses chitin, is obligately barophilic and has a DNA G $+\mathrm{C}$ content of $45.7 \mathrm{~mol} \%$. The similarity value between strain $\mathrm{ABE}-1^{\mathrm{T}}$ and C. psychrerythraea was $92.9 \%$ on the basis of $16 \mathrm{~S}$ rRNA sequencing, and the DNA-DNA relatedness value between strain ABE- $1^{\mathrm{T}}$ and $C$. psychrerythraea was $22 \%$. These values also indicate that these two strains do not belong to the same species.

Colwellia-like gas vacuolate bacterium strain S51W(gv)1 (Gosink \& Staley, 1995), from the Antarctic sea, exhibits a high 16S rRNA sequence similarity value with strain $\mathrm{ABE}-1^{\mathrm{T}}(97 \cdot 8 \%)$. Strain $\mathrm{ABE}-1^{\mathrm{T}}$ can

Table 1. Characteristics of genus Colwellia and genera that commonly occur in marine habitats

Data were obtained from the following references: Akagawa-Matsushita et al. (1992); Baumann et al. (1984); Collins \& Jones (1981); D'aoust \& Kunshner (1972); Deming et al. (1988); Dobson \& Franzmann (1996); Gauthier et al. (1995); MacDonell \& Colwell (1985); and Van Landschoot \& De Ley (1983). 1, Colwellia; 2, Vibrio; 3, Photobacterium; 4, Moritella; 5, Alteromonas; 6, Pseudoalteromonas; 7, Shewanella; 8, Halomonas; and 9, Marinomonas. +, Positive; -, negative; ND, not determined.

\begin{tabular}{|c|c|c|c|c|c|c|c|c|c|}
\hline & 1 & 2 & 3 & 4 & 5 & 6 & 7 & 8 & 9 \\
\hline $\mathrm{Na}^{+}$requirement for growth & + & + & + & + & + & + & + & + & + \\
\hline Fermentation of glucose & - & + & + & + & - & - & - & - & - \\
\hline Respiration & + & + & + & + & + & + & + & + & + \\
\hline Major isoprenoid quinone(s) & Q-8 & MK-8, Q-8, Q-9 & ND & $\mathrm{ND}$ & Q-8 & Q-8 & MK-7, Q-7, Q-8 & Q-9 & Q-8 \\
\hline Marine inhabitant & + & + & + & + & + & + & + & + & + \\
\hline DNA G $+\mathrm{C}(\mathrm{mol} \%)$ & $39-46$ & $38-51$ & $40-44$ & $42 \cdot 2$ & $44-47$ & $37-50$ & $44-47$ & $52-68$ & $44-48$ \\
\hline
\end{tabular}


be differentiated from strain $\mathrm{S} 51-\mathrm{W}(\mathrm{gv}) 1$ in that strain S51-W(gv)l does not contain a unique trans-unsaturated fatty acid in the membrane lipid (Gosink \& Staley, 1995). Furthermore, strain ABE- $1^{\mathrm{T}}$ is not a gas vacuolate bacterium.

DeLong et al. (1997) studied the evolutionary relationship of cultivated psychrophilic and barophilic deep-sea bacteria. All the strains used in their experiments were affiliated with one of five genera: $\mathrm{Col}$ wellia, Shewanella, Photobacterium, Moritella and a new group. Bowman et al. (1997c) estimated the diversity of psychrophilic bacteria from Antarctic sea ice. Their results revealed that these psychrophilic strains contained both Colwellia species and a closely related group. These results indicated that the genus Colwellia is well-distributed in cold sea environments.

DeLong et al. (1993) and Moyer et al. (1995) cloned Colwellia-like rRNA from isolates from Santa Barbara, California, USA, in the spring season (AGG53) and the hydrothermal vent system (PVB OTU12), respectively. These results suggested that the genus Colwellia consists not only of psychrophiles, but also of mesophiles or thermophiles. However, further studies are necessary to establish this. Interestingly, considering only isolated strains, there have been no reports of the isolation of Colwellia species from any environments other than cold ones.

On the basis of the above results, the name Colwellia maris sp. nov. is proposed and the type strain is designated $\mathrm{ABE}-1^{\mathrm{T}}$. A description of the new species is given below.

\section{Description of Colwellia maris sp. nov.}

Colwellia maris sp. nov. (mar'is. L. gen. n. maris of the sea).

Cells are curved rods $(0 \cdot 6-1 \cdot 0$ by $2-4 \mu \mathrm{m})$, Gramnegative and motile by means of a single polar flagellum. Catalase and oxidase reactions are positive. Acids are produced from D-glucose under aerobic conditions; however, no acids are produced in anaerobic conditions. No acids are produced from Larabinose. $\mathrm{D}$-fructose, maltose, $\mathrm{D}$-mannose, melibiose and sucrose either aerobically or anaerobically. No growth is observed in the absence of $\mathrm{NaCl}$ in the culture medium, but growth occurs in media supplemented with 3 and $4 \% \mathrm{NaCl}$ and not in media with salinity higher than $6.5 \% \mathrm{NaCl}$. Susceptibility to vibriostatic compound $\mathrm{O} / 129(10$ and $150 \mu \mathrm{g})$ is observed. Growth occurs at $0-22{ }^{\circ} \mathrm{C}$, but not at temperatures higher than $25^{\circ} \mathrm{C}$. Voges-Proskauer test, methyl red test and indole production are negative, but reduction of nitrate is positive. Hydrolyses gelatin, DNA and Tweens 20, 40, 60 and 80, but does not hydrolyse casein, chitin, starch and alginic acid. Utilizes D-glucose as a sole carbon and energy source for growth, but not D-mannose, raffinose, D-xylose, Larabinose, D-fructose, glycerol, lactose, maltose, melibiose and sucrose. The major isoprenoid quinone is
Q-8. The whole-cell fatty acids contain saturated and monounsaturated fatty acids with $10-18 \mathrm{C}$ atoms; saturated and mono-unsaturated $\mathrm{C}_{16}$ fatty acids are predominant in cells grown at $15^{\circ} \mathrm{C}$. The strain contains a unique trans-unsaturated fatty acid (9trans-hexadecenoic acid, $\left.\mathrm{C}_{16: 1} 9 t\right)$. The DNA $\mathrm{G}+\mathrm{C}$ content is $39.4 \mathrm{~mol} \%$ (determined by HPLC). The type strain of Colwellia maris is $\mathrm{ABE}-1^{\mathrm{T}}$ (= JCM $\left.10085^{\mathrm{T}}\right)$.

\section{ACKNOWLEDGEMENTS}

The authors would like to thank Dr Y. Nodasaka (Hokkaido University) for his help with transmission electron microscopic observation and Dr K.-I. Suzuki (Japan Collection of Microorganisms, Institute of Physical and Chemical Research) for critically reading the manuscript.

\section{REFERENCES}

Akagawa-Matsushita, M., Itoh, T., Katayama, Y., Kuraishi, H. \& Yamasato, K. (1992). Isoprenoid quinone composition of some marine Alteromonas, Marinomonas, Deleya, Pseudomonas and Shewanella species. J Gen Microbiol 138, 2275-2281.

Barrow, G. L. \& Feltham, R. K. A. (1993). Cowan and Steel's Manual for the Identification of Medical Bacteria, 3rd edn. Cambridge: Cambridge University Press.

Baumann, P., Ralph, H. \& Schubert, W. (1984). The Vibrionaceae. In Bergey's Manual of Systematic Bacteriology, vol. 1, pp. 516-550. Edited by N. R. Krieg \& J. H. Holt. Baltimore: Williams \& Wilkins.

Bowman, J. P., McCammon, S. A. \& Skerratt, J. H. (1997a). Methylosphaera hansonii gen. nov., sp. nov., a psychrophilic, group I methanotroph from Antarctic marine-salinity, meromictic lakes. Microbiology 143, 1451-1459.

Bowman, J. P., McCammon, S. A., Brown, J. L., Nichols, P. D. \& McMeekin, T. A. (1997b). Psychroserpens burtonensis gen. nov., sp. nov., and Gelidibacter algens gen. nov., sp. nov., psychrophilic bacteria isolated from Antarctic lacustrine and sea ice habitats. Int J Syst Bacteriol 47, 670-677.

Bowman, J. P., McCammon, S. A., Brown, M. V., Nichols, D. S. \& McMeekin, T.A. (1997c). Diversity and association of psychrophilic bacteria in Antarctic sea ice. Appl Environ Microbiol 63, 3068-3078.

Bozal, N., Tudela, E., Rosselló-Mora, R., Lalucat, J. \& Guinea, J. (1997). Pseudoalteromonas antarctica sp. nov., isolation from an Antarctic coastal environment. Int J Syst Bacteriol 47, 345-351.

Brosius, J., Palmer, J. L., Kennedy, J. P. \& Noller, H. F. (1978). Complete nucleotide sequence of a $16 \mathrm{~S}$ ribosomal RNA gene from Escherichia coli. Proc Natl Acad Sci USA 75, 4801-4805.

Carbon, P., Ehresmann, C., Ehresmann, B. \& Ebel, J. P. (1979). The complete nucleotide sequence of the ribosomal 16-S RNA from Escherichia coli. Eur J Biochem 100, 399-410.

Collins, M. D. \& Jones, D. (1981). Distribution of isoprenoid quinone structure types in bacterial and their taxonomic implications. Microbiol Rev 45, 316-354.

D'aoust, J. Y. \& Kunshner, D. J. (1972). Vibrio psychroerythrus sp. $\mathrm{n}$. : classification of the psychrophilic marine bacterium, NRC 1004. J Bacteriol 111, 340-342.

DeLong, E. F., Franks, D. G. \& Alldredge, A. L. (1993). Phylogenetic diversity of aggregate vs. free-living marine bacterial assemblages. Limnol Oceanogr 38, 924-934. 
DeLong, E. F., Franks, D. G. \& Yayanos, A. A. (1997). Evolutionary relationship of cultivated psychrophilic and barophilic deep-sea bacteria. Appl Environ Microbiol 63, 2105-2108.

Deming, J. W., Somers, L. K., Straube, W. L., Swartz, D. G. \& Macdonell, M. T. (1988). Isolation of an obligately barophilic bacterium and description of a new genus, Colwellia gen. nov. Syst Appl Microbiol 10, 152-160.

Dobson, S. J. \& Franzmann, P. D. (1996). Unification of genera Deleya (Baumann et al. 1983), Halomonas (Vreeland et al. 1980), and Halovibrio (Fendrich 1988) and the species Paracoccus halodenitrificans (Robinson and Gibbons 1952) into a single genus, Halomonas, and placement of the genus Zymobacter in the family Halomonadaceae. Int $J$ Syst Bacteriol 46, 550-558.

Ezaki, T., Hashimoto, Y. \& Yabuuchi, E. (1989). Fluorometric deoxyribonucleic acid-deoxyribonucleic acid hybridization in microdilution wells as an alternative to membrane filter hybridization in which radioisotopes are used to determine genetic relatedness among bacterial strains. Int J Syst Bacteriol 39, 224-229.

Gauthier, G., Gauthier, M. \& Christen, R. (1995). Phylogenetic analysis of the genera Alteromonas, Shewanella, and Moritella using genes coding for small-subunit rRNA sequences and division of the genus Alteromonas into two genera, Alteromonas (emended) and Pseudoalteromonas gen. nov., and proposal of twelve new species combinations. Int $J$ Syst Bacteriol 45, 755-761.

Gosink, J. J. \& Staley, J. T. (1995). Biodiversity of gas vacuolate bacteria from Antarctic sea ice and water. Appl Environ Microbiol 61, 3486-3489.

Gounot, A.-M. (1976). Effects of temperature on the growth of psychrophilic bacteria from glaciers. Can $J$ Microbiol 22, 839-846.

Holt, J. G., Krieg, N. R., Sneath, P. H. A., Staley, J. T. \& Williams, S. T. (1994). Bergey's Manual of Determinative Bacteriology, 9th edn. Baltimore: Williams \& Wilkins.

Horikoshi, K. \& Grant, W. D. (1991). Superbugs. Tokyo: Japan Scientific Societies Press.

Irgens, R. L., Gosink, J. J. \& Staley, J. T. (1996). Polaromonas vacuolata gen. nov., sp. nov., a psychrophilic, marine, gas vacuolate bacterium from Antarctica. Int J Syst Bacteriol 46, $822-826$.

Ishii, A., Imagawa, S., Fukunaga, N., Sasaki, S., Minowa, O., Mizuno, Y. \& Shiokawa, H. (1987). Isozymes of isocitrate dehydrogenase from an obligate psychrophilic bacterium, Vibrio sp. strain ABE-1: purification, and modulation of activities by growth conditions. J Biochem 102, 1489-1498.

Ishii, A., Suzuki, M., Sahara, T., Takada, Y., Sasaki, S. \& Fukunaga, N. (1993). Genes encoding two isocitrate dehydrogenase isozymes of a psychrophilic bacterium, Vibrio sp. strain ABE-1. $J$ Bacteriol 175, 6873-6880.

Kimura, M. (1980). A simple method for estimating evolutionary rates of base substitution through comparative studies of nucleotide sequences. $J$ Mol Evol 16, 111-120.

Leifson, E. (1963). Determination of carbohydrate metabolism of marine bacteria. J Bacteriol 85, 1183-1184.
MacDonell, M. T. \& Colwell, R. R. (1985). Phylogeny of Vibrionaceae and recommendation for two genera, Listonella and Shewanella. Syst Appl Microbiol 6, 171-182.

Marmur, J. (1961). A procedure for the isolation of deoxyribonucleic acid from micro-organisms. J Mol Biol 3, 208-218.

Morita, R. Y. (1975). Psychrophilic bacteria. Bacteriol Rev 39 , $144-167$.

Morita, R. Y. \& Haight, R. D. (1964). Temperature effects on the growth of an obligate psychrophilic marine bacterium. Limnol Oceanogr 9, 102-106.

Moyer, C. L., Dobbs, F. C. \& Karl, D. M. (1995). Phylogenetic diversity of the bacterial community from a microbial mat at an active, hydrothermal vent system, Loihi seamount, Hawaii. Appl Environ Microbiol 61, 1555-1562.

Okuyama, H., Sasaki, S., Higashi, S. \& Murata, N. (1990). A transunsaturated fatty acid in a psychrophilic bacterium, Vibrio sp. strain ABE-1. J Bacteriol 172, 3515-3518.

Okuyama, H., Okajima, N., Sasaki, S., Higashi, S. \& Murata, N. (1991). The cis/trans isomerization of the double bond of fatty acid as a strategy for adaptation to changes in ambient temperature in the psychrophilic bacterium, Vibrio sp. strain ABE-1. Biochim Biophys Acta 1084, 13-20.

Pacha, R. E. (1968). Characteristics of Cytophaga psychrophila (Borg) isolated during outbreaks of bacterial cold-water disease. Appl Microbiol 21, 97-101.

Saitou, N. \& Nei, M. (1987). The neighbor-joining method: a new method for reconstructing phylogenetic trees. Mol Biol Evol 4 , $406-425$.

Takada, Y., Ochiai, T., Okuyama, H., Nishi, K. \& Sasaki, S. (1979). An obligately psychrophilic bacterium isolated on the Hokkaido coast. J Gen Appl Microbiol 25, 11-19.

Takada, Y., Fukunaga, N. \& Sasaki, S. (1981). Temperaturedependence and distribution of NADH dehydrogenase in a psychrophilic bacterium, Vibrio sp. strain ABE-1. J Gen Appl Microbiol 27, 327-337.

Takada, Y., Fukunaga, N. \& Sasaki, S. (1989a). Coupling site of the respiration-dependent sodium pump in a psychrophilic bacterium, Vibrio sp. strain ABE-1. J Gen Appl Microbiol 35, $33-42$.

Takada, Y., Fukunaga, N. \& Sasaki, S. (1989b). Identification of respiratory quinones from a psychrophilic bacterium, Vibrio sp. strain ABE-1. Agric Biol Chem 53, 3047-3049.

Takada, Y., Fukunaga, N. \& Sasaki, S. (1991). $\mathrm{Na}^{+}$-driven ATP synthesis of a psychrophilic marine bacterium, Vibrio sp., strain ABE-1. FEMS Microbiol Lett 82, 225-228.

Tamaoka, J. \& Komagata, K. (1984). Determination of base composition by reversed-phase high-performance liquid chromatography. FEMS Microbiol Lett 25, 125-128.

Thompson, J. D., Higgins, D. G. \& Gibson, T. J. (1994). CLUSTAL $\mathrm{W}$ : improving the sensitivity of progressive multiple sequence weighing, position-specific gap penalties and weight matrix choice. Nucleic Acids Res 22, 4673-4680.

Van Landschoot, A. \& De Ley, J. (1983). Intra- and intergeneric similarities of the rRNA cistron of Alteromonas, Marinomonas (gen. nov.) and some other Gram-negative bacteria. $J$ Gen Microbiol 129, 3057-3074. 